\title{
OXIDATION OF MOLYBDENUM BY LOW-ENERGY OXYGEN-ION BOMBARDMENT
}

\section{OKSIDACIJA MOLIBDENA Z NIZKOENERGETSKIM KISIKOVIM IONSKIM OBSTRELJEVANJEM}

\author{
Ivana Jelovica Badovinac, Ivna Kavre Piltaver, Iva Šarić, Robert Peter, \\ Mladen Petravić \\ University of Rijeka, Department of Physics and Center for Micro- and Nanosciences and Technologies, 51000 Rijeka, Croatia
} ijelov@phy.uniri.hr

Prejem rokopisa - received: 2016-07-15; sprejem za objavo - accepted for publication: 2016-11-17

doi:10.17222/mit.2016.199

We have studied the oxidation of pure molybdenum metal at room temperature (RT) by low-energy oxygen-ion bombardment within an analytical, ultrahigh vacuum chamber, using x-ray photoemission spectroscopy (XPS) around the Mo $3 \mathrm{~d}$ core level. We provide a detailed characterization of the oxidation states of pure Mo and a comparison with the Mo oxidation in the CoCrMo alloy. After the thermal oxidation of pure metal at RT up to $5000 \mathrm{~L}$ of oxygen, the Mo $3 \mathrm{~d}$ photoelectron remained almost unchanged. On the other hand, Mo oxidizes quite easily within the CoCrMo alloy by thermal oxidation at RT. The XPS spectra recorded after the ion bombardment showed a complex structure consisting of $\mathrm{Mo}^{4+}, \mathrm{Mo}^{5+}$ and $\mathrm{Mo}^{6+}$ oxidation states. Our study shows that pure Mo metal oxidizes more efficiently under oxygen-ion bombardment or when incorporated into the CoCrMo alloy. We explain our results in terms of the implantation dynamics of oxygen ions and the enhanced mobility and reactivity of oxygen atoms in the alloy, compared to the pure Mo metal.

Keywords: molybdenum, CoCrMo alloy, ion-beam oxidation, thermal oxidation, x-ray photoelectron spectroscopy

Z rentgensko fotoemisijsko spektroskopijo (angl. XPS) smo preučevali oksidacijo čiste kovine molibdena (Mo) pri sobni temperaturi (angl. RT) z obstreljevanjem z nizkoenergetskim ionskim žarkom kisika znotraj komore z ultravisokim vakuumom. V študiji smo predstavili podrobno karakterizacijo oksidacije čiste kovine Mo in jo primerjali z oksidacijo Mo v CoCrMo zlitini. Po termični oksidaciji Mo v čisti kovini pri sobni temperaturi z odmerki kisika do 5000 L, fotoemisijski spekter Mo $3 \mathrm{~d}$ lupinskega nivoja ostane skoraj nespremenjen. Nasprotno temu, Mo oksidira z lahkoto v CoCrMo zlitini s postopkom termične oksidacije pri sobni temperaturi. Po drugi strani pa so XPS-spektri, posneti po ionskem obstreljevanju, pokazali kompleksno strukturo, ki jo sestavljajo oksidacijska stanja $\mathrm{Mo}^{4+}, \mathrm{Mo}^{5+}$ ter $\mathrm{Mo}^{6+}$. Naša študija kaže, da čisti Mo oksidira bolj učinkovito, če je obstreljevan z ioni kisika ali če je vključen v CoCrMo zlitino. Naše rezultate lahko interpretiramo v smislu implementacijske dinamike kisikovih ionov ter večje mobilnosti in reaktivnosti kisikovih atomov v zlitini, v primerjavi s čisto kovino Mo.

Ključne besede: molibden, CoCrMo zlitina, oksidacija z ionskim žarkom, termična oksidacija, rentgenska fotoemisijska spektroskopija

\section{INTRODUCTION}

The CoCrMo alloy is currently one of the most important materials for biomedical applications due to its superior wear resistance, hardness and high corrosion resistance. It is frequently used for metal-on-metal hip resurfacing joints. ${ }^{1}$ The possible release of metal ions due to corrosion is thought to have adverse effects on the surrounding body tissue and ultimately leads to the failure of the implant. The release of the metallic ions into the body tissue can be prevented by the formation of a thin oxide layer on the surface of the implant. ${ }^{2}$ Thus, it is important to fully understand the oxidation mechanism of the CoCrMo alloy, which seems to be quite complex ${ }^{3}$ and requires a knowledge of the oxidation mechanisms of each metallic component. In the present paper we focus on the oxidation behaviour of molybdenum.

An additional motivation to study the oxidation of molybdenum is related to the variety of applications of molybdenum oxide films, such as heterogeneous chemistry and catalysis, microelectronics and nanotechnol- ogy. ${ }^{4,5}$ Molybdenum oxides are important catalysts or catalyst precursors exhibiting catalytic properties in both selective oxidation and selective hydrogenation reactions. ${ }^{6}$ Also, both pure molybdenum oxides or mixtures with tungsten oxide are promising display materials due to changes of their colour reversibly upon light irradiation. ${ }^{7}$ Although molybdenum oxides are used in a variety of applications, the nature and catalytic properties of these materials are not yet fully understood. Since molybdenum has several oxidation states, ranging from +2 to +6 , a variety of its oxide compounds may co-exist on the same surface. Therefore, any application of molybdenum oxides requires a detailed knowledge of the molybdenum oxidation states within the sample. Molybdenum oxide surfaces of varying chemical composition, complexity, crystallinity and intercalation have been extensively analyzed, especially with XPS..$^{8-12}$ However, the interpretation of the results has not been consistent in the literature due to the complexity of the XPS spectra, particularly when samples include different oxidation states. ${ }^{13}$ 
It has been shown previously that the Mo surface is quite resistant to the thermal oxidation at temperatures below $300{ }^{\circ} \mathrm{C} .{ }^{8}$ On the other hand, the ion-bombardment represents an efficient method for the oxidation of different metallic and semiconductor surfaces with controlled amount of oxidation and oxide thickness, even at room temperature. ${ }^{7-10}$ In our previous studies, we have shown that oxygen bombardment is more efficient in creating the oxide films on $\mathrm{Ni}$ and $\mathrm{Co}$ surfaces than oxidation by electrochemical methods or thermal oxidation. ${ }^{14,15}$

In this paper we provide a detailed characterization of the RT oxidation of pure Mo metal by low-energy oxygen-ion bombardment or thermal oxidation in an oxygen atmosphere using X-ray photoelectron spectroscopy (XPS) and compare these results with the oxidation of Mo in the CoCrMo alloy.

\section{EXPERIMENTAL PART}

The Mo metal foil (M. Woite GmbH, $99.95 \%$ of mass fractions of $\mathrm{Mo}$ ) and CoCrMo alloy (58\% Co, $32 \% \mathrm{Cr}, 6 \% \mathrm{Mo}, 1.3 \% \mathrm{Si}$ ) samples were first polished with $\mathrm{SiC}$ papers of 800-2500 grit and then washed with ethanol and redistilled water. Before any oxidation step, the Mo and CoCrMo surfaces were additionally cleaned within the analytical ultrahigh vacuum (UHV) chamber by cycles of low energy $\mathrm{Ar}^{+}$bombardment at room temperature (these samples are referred to as cleaned samples). All the oxidation was conducted in situ in the main chamber of the XPS instrument with a broad beam of $500 \mathrm{eV} \mathrm{O}_{2}{ }^{+}$ions of the typical current density of $2 \mu \mathrm{A} / \mathrm{cm}^{2}$. The thermal oxidation was performed by supplying the pure oxygen gas into the UHV chamber to a pressure of $6.5 \times 10^{-4} \mathrm{~Pa}$. In this case, the oxidation dose is expressed in units of Langmuir, defined as $1 \mathrm{~L}=$ $1.33 \times 10^{-4} \mathrm{~Pa}$.

Cleaned and oxidised Mo surfaces were characterized by XPS in a SPECS XPS spectrometer equipped with a Phoibos MCD 100 electron analyser and a monochromatized source of Al- $K_{\alpha}$ X-rays of $1486.74 \mathrm{eV}$. The typical pressure in the UHV chamber during the XPS analysis was in the $10^{-7} \mathrm{~Pa}$ range. For the electron pass energy of the hemispherical electron energy analyser of $10 \mathrm{eV}$ used in the present study, the overall energy resolution was around $0.8 \mathrm{eV}$. The photoemission spectra were simulated with several sets of mixed GaussianLorentzian functions with Shirley background subtraction using Unifit software. ${ }^{16}$

\section{RESULTS AND DISCUSSION}

The formation of different Mo-O bonds, related to the different oxidation states of the Mo, can be extracted from the chemical shifts in the photoemission spectra around the Mo 3d core-levels. We start with the thermal oxidation of Mo metal. In Figure 1 we show several characteristic Mo 3d photoemission spectra taken on the cleaned surface and surfaces oxidized with two different oxygen doses at RT. The cleaned sample shows a characteristic spin-orbit splitting of $3.1 \mathrm{eV}$ of the Mo $3 \mathrm{~d}$ level to Mo $3 \mathrm{~d}_{3 / 2}$ and Mo $3 \mathrm{~d}_{5 / 2}$, at binding energies (BEs) of 231.2 and $228.1 \mathrm{eV}$, respectively. This doublet is assigned to the metallic state of $\mathrm{Mo}, \mathrm{Mo}^{0}$, in good agreement with the data from the literature. ${ }^{8,9,11}$ After thermal oxidation at RT, shown in Figure 1, the Mo 3d photoemission remains almost unchanged up to the highest oxygen dose of $5000 \mathrm{~L}$ used in this study. This is in agreement with the previous studies of Mo oxidation, in which the thermal oxidation of Mo requires temperatures above $300{ }^{\circ} \mathrm{C} .{ }^{8}$

On the other hand, bombardment with $\mathrm{O}_{2}{ }^{+}$ions leads to significant changes in the photoemission spectra, with the development of several new and well-defined peaks around the Mo 3d level. As an example, we show in Figure 2 several Mo 3d spectra taken from a cleaned Mo surface and surfaces bombarded with $500 \mathrm{eV} \mathrm{O}_{2}{ }^{+}$ions for two different bombardment times of $5 \mathrm{~min}$ and $20 \mathrm{~min}$, corresponding to the oxygen doses of $4.75 \times 10^{15}$ $\mathrm{O}$ atoms $/ \mathrm{cm}^{2}$ and $1.5 \times 10^{16} \mathrm{O}$ atoms $/ \mathrm{cm}^{2}$, respectively. Obviously, the oxygen bombardment is more efficient for the formation of some new Mo bonds on the metal surface than the thermal oxidation.

The Mo 3d spectra of ion-bombarded surfaces show a quite complex structure. To identify the different components within that structure we fitted the experimental curves from Figure 2 with the set of Voigt functions, as shown in Figure 3. We first note that the deconvolution

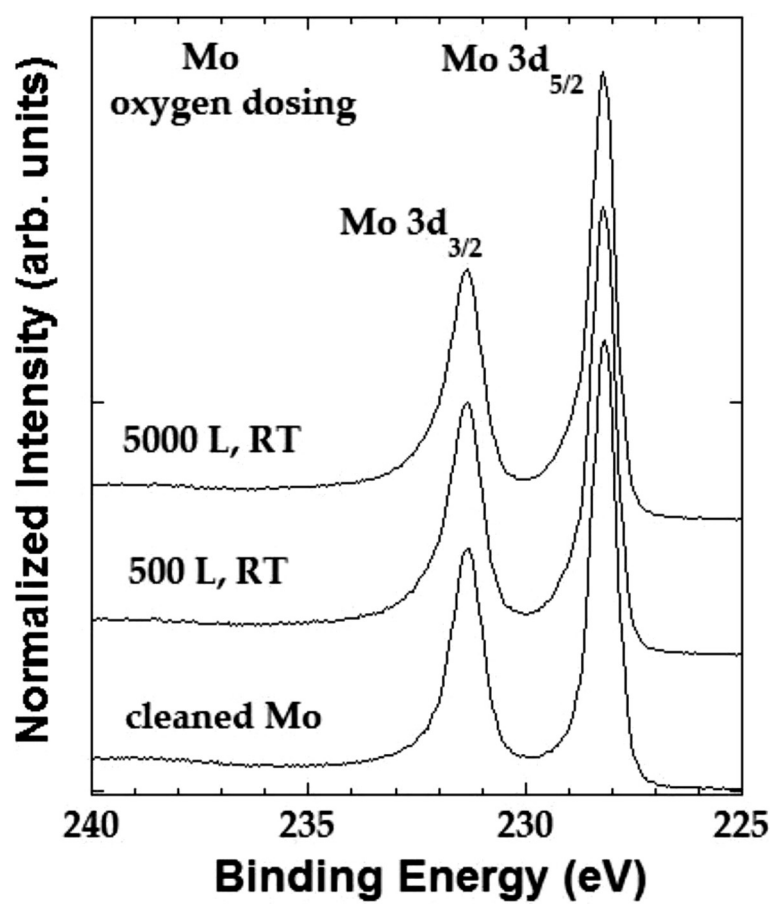

Figure 1: Mo 3d core-level photoemission spectra from a cleaned molybdenum surface and surfaces oxidized at room temperature (RT) with oxygen doses of $500 \mathrm{~L}$ and $5000 \mathrm{~L}$ 


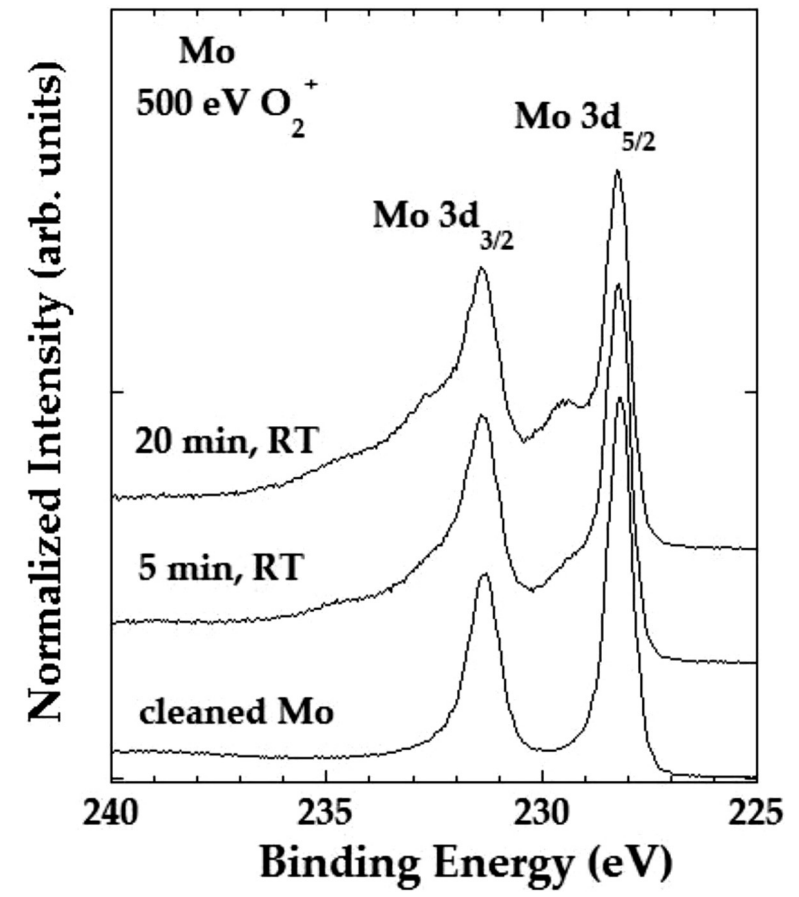

Figure 2: Mo 3d core-level photoemission spectra from a cleaned molybdenum surface and surfaces bombarded with $500 \mathrm{eV} \mathrm{O}_{2}{ }^{+}$ions for $5 \mathrm{~min}$ and $20 \mathrm{~min}$ at room temperature (RT)

of the Mo $3 \mathrm{~d}$ spectrum from the cleaned sample is dominated by the Mo $3 \mathrm{~d}_{5 / 2}-$ Mo $3 \mathrm{~d}_{3 / 2}$ doublet assigned to the $\mathrm{Mo}^{0}$ emission. However, a good fit of the experimental curve is obtained only by introducing two small additional doublets, with the main Mo $3 \mathrm{~d}_{5 / 2}$ components

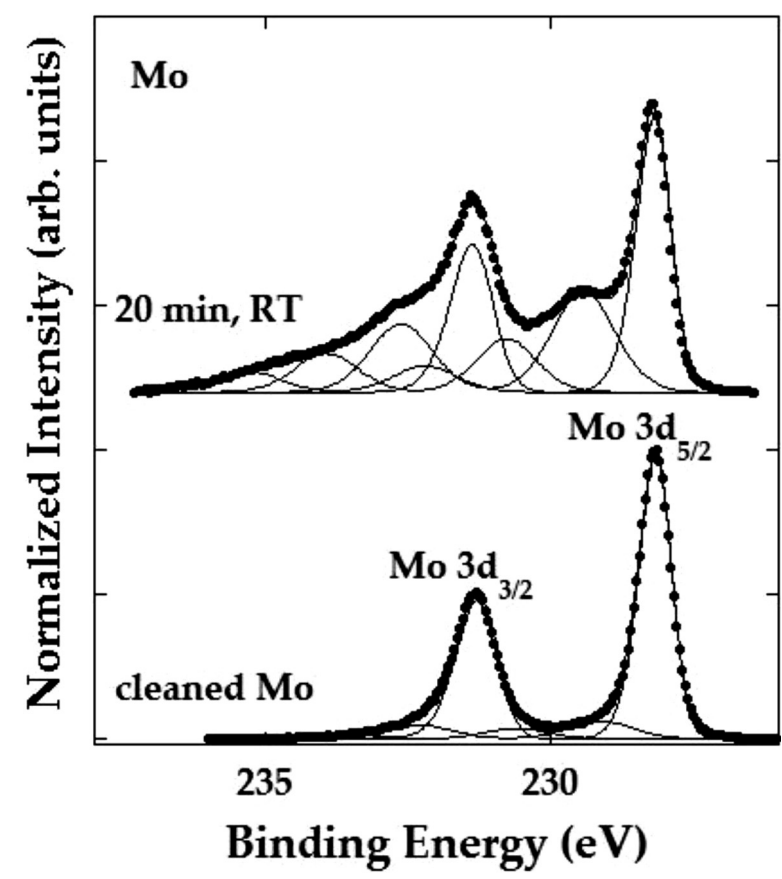

Figure 3: The deconvoluted Mo 3d spectra from a cleaned molybdenum sample and a sample exposed to $500 \mathrm{eV} \mathrm{O}_{2}{ }^{+}$ions at RT for 20 min; solid lines represent product of Gaussians and Lorentzians, while closed circles represent experimental XPS spectra at $229.4 \mathrm{eV}$ and $230.7 \mathrm{eV}$, respectively. We assign these components to the intrinsic oxygen, most likely in the form of $\mathrm{MoO}_{2}$ or $\mathrm{Mo}_{2} \mathrm{O}_{5}$, present in the Mo foil that has not been removed with our cleaning procedure.

Deconvolution of the spectrum from a sample bombarded to a high ion fluence of $1.5 \times 10^{16} \mathrm{O}$ atoms $/ \mathrm{cm}^{2}$ (i.e., for the 20-minute bombardment time, shown in Figure 3), exhibits three well-resolved doublets in addition to the $\mathrm{Mo}^{0}$ doublet, with the dominant Mo $3 \mathrm{~d}_{5 / 2}$ peaks at BEs of 229.4, 230.8 and $232.2 \mathrm{eV}$, respectively. We assign these additional components to the emission from $\mathrm{MoO}_{2}, \mathrm{Mo}_{2} \mathrm{O}_{5}$ and $\mathrm{MoO}_{3}$, respectively, i.e., from the $\mathrm{Mo}^{4+}, \mathrm{Mo}^{5+}$ and $\mathrm{Mo}^{6+}$ oxidation states of $\mathrm{Mo}$, respectively, in good agreement with the data from the literature. ${ }^{8,9,11}$

Turning now to the oxidation of the CoCrMo alloy shown in Figure 4, we first note that the Mo 3d XPS spectrum of the cleaned CoCrMo sample is almost identical to the spectrum from the cleaned Mo metal foil from Figure 1. Furthermore, the thermal oxidation of Mo at RT in the alloy is more efficient than the thermal oxidation of the pure metal at RT to the same dose of $5000 \mathrm{~L}$, clearly showing the formation of $\mathrm{MoO}_{2}\left(\mathrm{Mo}^{4+}\right.$ oxidation state), $\mathrm{Mo}_{2} \mathrm{O}_{5}\left(\mathrm{Mo}^{5+}\right.$ oxidation state) and $\mathrm{MoO}_{3}$ $\left(\mathrm{Mo}^{6+}\right.$ oxidation state). These oxidation states are represented in Figure 4 by three fitting doublets, in addition to the $\mathrm{Mo}^{0}$ doublet. Finally, the ion-bombardment of CoCrMo shows the different oxide structure of Mo, compared to the metallic molybdenum. Now the contribution from the $\mathrm{Mo}^{6+}$ states dominates the spectrum, as indicated in Figure 4 for the sample bombarded with $500 \mathrm{eV} \mathrm{O}_{2}{ }^{+}$ions for $20 \mathrm{~min}$. At the same time, the

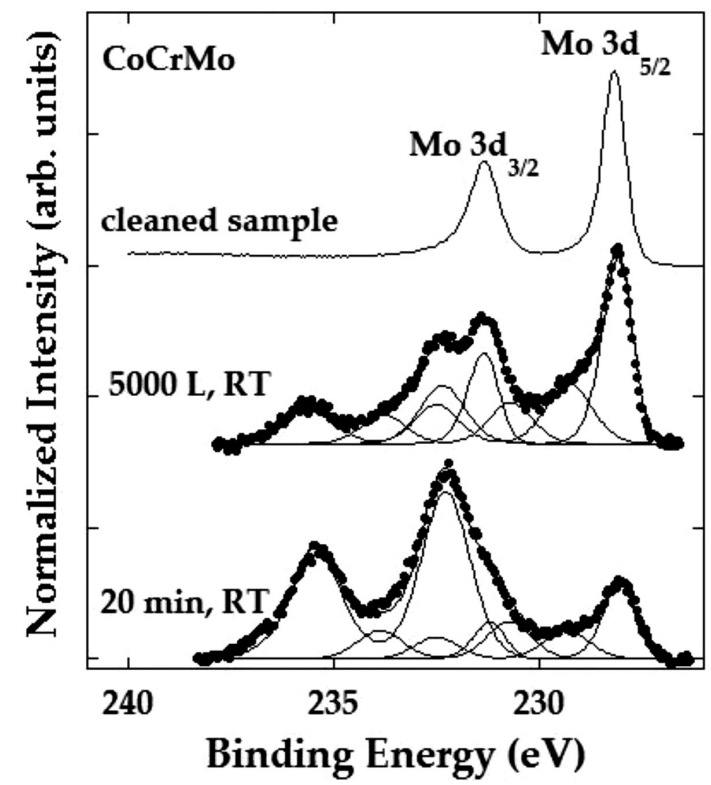

Figure 4: Comparison of Mo 3d core-level XPS spectra from a cleaned CoCrMo surface and surfaces oxidized at RT with $5000 \mathrm{~L}$ of oxygen or bombarded with $500 \mathrm{eV} \mathrm{O}_{2}{ }^{+}$ions for $20 \mathrm{~min}$ (closed circles); the three fitting doublets of each spectrum (solid lines, representing product of Gaussians and Lorentzians) correspond to the emission from $\mathrm{MoO}_{2}, \mathrm{Mo}_{2} \mathrm{O}_{5}$ and $\mathrm{MoO}_{3}$ 


\section{JELOVICA BADOVINAC et al.: OXIDATION OF MOLYBDENUM BY LOW-ENERGY OXYGEN-ION BOMBARDMENT}

$\mathrm{Mo}^{0}$ component in the spectrum is greatly reduced. We stress here that the $\mathrm{Mo}^{0}$ peak is present in all ion-bombarded or thermally oxidised samples, indicating the formation of very thin oxide films on the surface. In such case, the XPS signal includes a contribution from the underlying metallic molybdenum.

The $\mathrm{O} 1 \mathrm{~s}$ photoemission (not shown) was also recorded from all the oxidized surfaces. While the intensity of the oxygen peaks increases with the bombardment time or dose of oxygen, indicating the increase of oxygen concentration within the surface layer, the shape of $\mathrm{O} 1 \mathrm{~s}$ peak does not show any significant changes. It is well known from the literature that the $\mathrm{O} 1 \mathrm{~s}$ binding energies of many metal oxides fall within a very narrow range and it is not possible to separate the individual oxide contributions. ${ }^{17}$ The main $\mathrm{O}$ 1s peak, observed in our spectra around $530 \mathrm{eV}$, is usually assigned to all metal oxides, while the small shoulder, observed in our spectra around $531.5 \mathrm{eV}$, is assigned to the surface hydroxide groups or oxygen defects. ${ }^{18,19}$

We conclude from the comparison of our results from Figures 1 to $\mathbf{4}$ that the ion bombardment provides a more efficient oxidation process for molybdenum than the thermal oxidation, while Mo oxidizes more efficiently in the CoCrMo alloy compared to the pure Mo metal. We attribute this behaviour to the enhanced mobility and reactivity of oxygen atoms in the alloy, compared to the pure Mo metal. On the other hand, in contrast to thermal processes, the ion-induced oxidation eliminates the need for elevated temperatures and bypasses several thermally activated processes, such as absorption, dissociation, diffusion or bond breaking. The atomic collisions between the impinging oxygen and matrix atoms create different defects within the material, which are known to enhance the mobility and reactivity of oxygen anions and metal cations. ${ }^{20-23}$ Our measurements of ion-bombarded samples show, indeed, the effects expected from the radiation-enhanced oxidation, as observed previously for some other metals and semiconductors. ${ }^{15,20,21,23}$

\section{CONCLUSION}

The thermal oxidation of Mo in pure Mo metal is not efficient at RT. However, Mo oxidises quite easily at RT within the CoCrMo alloy, showing characteristic contributions from the $\mathrm{Mo}^{4+}, \mathrm{Mo}^{5+}$ and $\mathrm{Mo}^{6+}$ oxidation states. The presence of $\mathrm{Co}$ and $\mathrm{Cr}$ reduces the surface barrier and enables a more efficient intake of oxygen within the sample.

On the other hand, the ion-induced oxidation of Mo is quite efficient at RT in both the Mo metal and the CoCrMo alloy. It is explained by the radiation-enhanced oxidation of Mo, as observed previously for some other metals and semiconductors. Again, contributions from the $\mathrm{Mo}^{4+}, \mathrm{Mo}^{5+}$ and $\mathrm{Mo}^{6+}$ oxidation states are present in all the oxides with the dominant contribution from the $\mathrm{Mo}^{6+}$ oxidation states for the high implantation doses of oxygen. Finally, the RT ion-induced oxidation of Mo is more efficient than thermal oxidation in both the CoCrMo alloy and the pure Mo metal samples.

\section{Acknowledgements}

This work was supported by the European Fund for Regional Development and the Ministry of Science, Education and Sports of the Republic of Croatia under the project Research Infrastructure for Campus-Based Laboratories at the University of Rijeka (grant number RC.2.2.06-0001); and the European Social Fund for Human Resources Development under the project SIZIF (grant number HR.3.2.01-0310).

\section{REFERENCES}

${ }^{1}$ J. Black, Biological Performance of Materials, Fundamentals of Biocompatibility, 3rd ed., New York 1999

${ }^{2}$ M. Metikoš-Huković, R. Babić, Some aspects in designing passive alloys with an enhanced corrosion resistance, Corrosion Science, 51 (2009), 70-75, doi:10.1016/j.corsci.2008.10.004

${ }^{3}$ I. Milošev, H.-H. Strehblow, The composition of the surface passive film formed on CoCrMo alloy in simulated physiological solution, Electrochimica Acta, 48 (2003), 2767-2773, doi:10.1016/S00134686(03)00396-7

${ }^{4}$ V. E. Henrich, P. A. Cox, The Surface Science of Metal Oxides, Cambridge University Press, Cambridge, 1996

${ }^{5}$ B. M. Weckhuysen, D. E. Keller, Chemistry, spectroscopy and the role of supported vanadium oxides in heterogeneous catalysis, Catal. Today, 78 (2003) 25

${ }^{6}$ L. E. Firment, A. Ferretti, Stoichiometric and oxygen deficient $\mathrm{MoO}_{3}(010)$ surfaces Stoichiometric and oxygen deficient $\mathrm{MoO}_{3}(010)$ surfaces Stoichiometric and oxygen deficient $\mathrm{MoO}_{3}(010)$ surfaces Stoichiometric and oxygen deficient $\mathrm{MoO}_{3}(010)$ surfaces Stoihiometric and oxygen deficient $\mathrm{MoO}_{3}$ (010) surfaces, Surf. Sci. 129 (1983), 155, doi:10.1016/0039-6028(83)90100-0

${ }^{7}$ P. A. Spevack, N. S. McIntyre, A Raman and XPS Investigation of Supported Molybdenum Oxide Thin Films, 1, Calcination and Reduction Studies, J. Phys. Chem., 97 (1993), 11020-11030, doi:10.1021/j100144a020

${ }^{8}$ S. I. Castañeda, I. Montero, J. M. Ripalda, N. Diaz, L. Galán, F. Rueda, X-ray photoelectron spectroscopy study of low-temperature molybdenum oxidation process, Journal of Applied Physics, 85 (1999), 8415-8418, doi: 10.1063/1.370690

${ }^{9}$ N. V. Alov, Surface oxidation of metals by oxygen ion bombardment, Nucl. Instr. and Meth. in Phys. Res. B, 256 (2007), 337-340, doi:10.1016/j.nimb.2006.12.023

${ }^{10}$ L. D. Lopez-Carreno, G. Benitez, L. Viscido, J. M. Heras, F. Yubero, J. P. Espinos, A. R. Gonzalez-Elipe, Oxidation of Molybdenum Surfaces by Reactive Oxygen Plasma and $\mathrm{O}_{2}$ Bombardment: an Auger and XPS Study, Surf. Interface Anal., 26 (1998), 235-241, doi: 10.1002/(SICI)1096-9918(199804)

${ }^{11}$ J. Baltrusaitis, B. Mendoza-Sanchez, V. Fernandez, R. Veenstra, N. Dukstiene, A. Roberts, N. Fairley, Generalized molybdenum oxide surface chemical state XPS determination via informed amorphous sample model, Applied Surface Science, 326 (2014), 151-161, doi:10.1016/j.apsusc.2014.11.077

${ }^{12}$ J. Światowska-Mrowiecka, S. de Diesbach, V. Maurice, S. Zanna, L. Klein, E. Briand, I. Vickridge, P. Marcus, Li-ion intercalation in thermal oxide thin films of $\mathrm{MoO}_{3}$ as studied by XPS, RBS, and NRA, The Journal of Physical Chemistry C, 112 (2008), 11050-11058, doi: 10.1021/jp800147f 


\section{MATERIALI IN TEHNOLOGIJE/MATERIALS AND TECHNOLOGY (1967-2017) - 50 LET/50 YEARS}

\section{JELOVICA BADOVINAC et al.: OXIDATION OF MOLYBDENUM BY LOW-ENERGY OXYGEN-ION BOMBARDMENT}

${ }^{13}$ B. Mendoza-Sánchez, T. Brousse, C. Ramirez-Castro, V. Nicolosi, P. S. Grant, An investigation of nanostructured thin film $\alpha-\mathrm{MoO}_{3}$ based supercapacitor electrodes in an aqueous electrolyte, Electrochimica Acta, 91 (2013), 253-260, doi:10.1016/j.electacta.2012.11.127

${ }^{14}$ M. Petravic, M. Varasanec, R. Peter, I. Kavre, M. Metikos-Hukovic, Y.-W. Yang, Electronic structure of nitinol surfaces oxidized by low-energy ion bombardment, J. Appl. Phys., 115 (2014), 243703-243708, doi:10.1063/1.4884835

${ }^{15}$ I. Saric, R. Peter, M. Petravic, Oxidation of Cobalt by Oxygen Bombardment at Room Temperature, J. Phys. Chem. C, (2016), 120 (39), 22421-22425, doi:10.1021/acs.jpcc.6b07139

${ }^{16}$ R. Hesse, T. Chassé, R. Szargan, Peak Shape Analysis of Core Level Photoelectron Spectra Using Unifit for Windows, Fresenius, J. Anal. Chem., 365 (1999), 48-54, doi:10.1007/s002160051443

${ }^{17}$ M. C. Biesinger, L. W. M. Lau, A. R. Gerson, R. St. C. Smart, Resolving surface chemical states in XPS analysis of first row transition metals, oxides and hydroxides: Sc, Ti, V, Cu and Zn, Appl. Surf. Sci., 257 (2010), 887-898, doi:10.1016/j.apsusc.2010.07.086

${ }^{18}$ M. C. Biesinger, B. P. Payne, A. P. Grosvenor, L. W. M. Lau, A. R. Gerson, R. St. C. Smart, Resolving surface chemical states in XPS analysis of first row transition metals, oxides and hydroxides: $\mathrm{Cr}$, $\mathrm{Mn}, \mathrm{Fe}, \mathrm{Co}$ and Ni, Appl. Surf. Sci., 257 (2011), 2717-2730, doi:10.1016/j.apsusc.2010.10.051
${ }^{19}$ S. C. Petitto, E. M. Marsh, G. A. Carson, M. A. Langell, Cobalt oxide surface chemistry: The interaction of $\mathrm{CoO}\left(\begin{array}{lll}1 & 0 & 0\end{array}\right), \mathrm{Co3O} 4\left(\begin{array}{ll}1 & 1\end{array}\right.$ $0)$, and Co3O4(l 11 1) with oxygen and water, Journal of Molecular Catalysis A, Chemical, 281 (2008), 49-58, doi:10.1016/j.molcata. 2007.08.023

${ }^{20}$ J. S. Williams, M. Petravic, B. G. Svensson, M. Conway, Oxidation of Silicon by Low-Energy Oxygen Bombardment, J. Appl. Phys., 76 (1994), 1840-1846, doi:10.1063/1.357704

${ }^{21}$ J. S. Williams, J. M. Poate, Ion Implantation and Beam Processing, Academic Press, Sydney, Australia, 1984

${ }^{22}$ G. J. Koel, P. J. Gellings, Contribution of Different Types of Point-Defects to Diffusion in $\mathrm{CoO}$ and $\mathrm{NiO}$ during Oxidation of Metals, Oxid. Met., 5 (1972), 185-203, doi:10.1007/BF00609658

${ }^{23}$ I. Saric, R. Peter, I. Kavre, I. J. Badovinac, M. Petravic, Oxidation of Nickel Surfaces by Low Energy Ion Bombardment, Nucl. Instrum. Meth. B, 371 (2016), 286-289, doi:10.1016/j.nimb.2015.08.090 